\title{
Janibacter hoylei sp. nov., Bacillus isronensis sp. nov. and Bacillus aryabhattai sp. nov., isolated from cryotubes used for collecting air from the upper atmosphere
}

\section{Correspondence \\ S. Shivaji \\ shivas@ccmb.res.in}

\author{
S. Shivaji, ${ }^{1}$ Preeti Chaturvedi, ${ }^{1}$ Zareena Begum, ${ }^{1}$ Pavan Kumar Pindi, ${ }^{1}$ \\ R. Manorama, ${ }^{1}$ D. Ananth Padmanaban, ${ }^{2}$ Yogesh S. Shouche, ${ }^{3}$ \\ Shrikant Pawar, ${ }^{3}$ Parag Vaishampayan, ${ }^{3}$ C. B. S. Dutt, ${ }^{4}$ G. N. Datta, \\ R. K. Manchanda, ${ }^{5}$ U. R. Rao, ${ }^{4}$ P. M. Bhargava ${ }^{6}$ and J. V. Narlikar ${ }^{7}$
${ }^{1}$ Centre for Cellular and Molecular Biology, Uppal Road, Hyderabad 500 007, India
${ }^{2}$ Microbial Type Culture Collection (MTCC), Institute of Microbial Technology, Sector 39A, Chandigarh 160 036, India
${ }^{3}$ Microbial Culture Collection, National Centre for Cell Science, Pune University Campus, Ganeshkhind, Pune 411 007, India \\ ${ }^{4}$ ISRO Headquarters, Department of Space, Bangalore 560 023, India \\ ${ }^{5}$ Tata Institute of Fundamental Research, Homi Bhabha Road, Colaba, Mumbai 400 005, India \\ ${ }^{6}$ Anveshna, 12-13-100, Lane No. 1, Street No. 3, Tarnaka, Hyderabad 500 017, India \\ ${ }^{7}$ Inter-University Centre for Astronomy and Astrophysics, Ganeshkhind, Post Bag 4, Pune 411007 , \\ India
}
Three novel bacterial strains, PVAS $-1^{\top}, \mathrm{B} 3 \mathrm{~W} 22^{\top}$ and $\mathrm{B} 8 \mathrm{~W} 22^{\top}$, were isolated from cryotubes used to collect air samples at altitudes of between 27 and $41 \mathrm{~km}$. Based on phenotypic characteristics, chemotaxonomic features, DNA-DNA hybridization with the nearest phylogenetic neighbours and phylogenetic analysis based on partial $16 \mathrm{~S}$ rRNA gene sequences (PVAS $-1^{\top}$, $1196 \mathrm{nt}$; B3W22 ${ }^{\top}, 1541 \mathrm{nt}$; B8W22 ${ }^{\top}, 1533 \mathrm{nt}$ ), the three strains were identified as representing novel species, and the names proposed are Janibacter hoylei sp. nov. (type strain PVAS $-1^{\top}$ $=$ MTCC $8307^{\top}=$ DSM $21601^{\top}=$ CCUG $56714^{\top}$ ), Bacillus isronensis sp. nov. (type strain

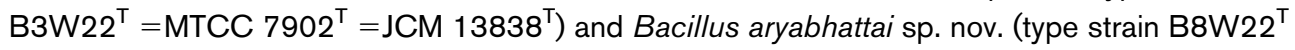 $=$ MTCC $7755^{\top}=J C M 13839^{\top}$ ).

Evidence for the occurrence of micro-organisms in the upper atmosphere at altitudes of 17-85 km (Bruch, 1967; Greene et al., 1964; Lysenko, 1979), obtained using a meteorological rocket (Imshenetsky et al., 1978; Lysenko, 1979), a specially designed direct-flow sampler (Greene et al., 1964; Rogers \& Meier, 1936) and cryosamplers sent up on a balloon (Harris et al., 2002; Wainwright et al., 2003; Shivaji et al., 2006), has established unequivocally that life forms are present in the upper atmosphere. To date, only a few studies have been published on the quantity and nature of the micro-organisms in the upper

The GenBank/EMBL/DDBJ accession numbers for the 16S rRNA gene sequences of strains PVAS $-1^{\top}, \mathrm{B} 3 \mathrm{~W} 22^{\top}$ and B8W22 ${ }^{\top}$ are DQ317608, EF114311 and EF114313.

Polar lipid profiles of the novel strains and related type strains and results of UV-sensitivity experiments are available as supplementary material with the online version of this paper. atmosphere (Bruch, 1967; Greene et al., 1964; Lysenko, 1979; Rogers \& Meier, 1936; Harris et al., 2002). In these earlier reports, the emphasis was on detection of micro-organisms rather than their identification. Wainwright et al. (2003) reported the presence of two bacterial species (Bacillus simplex and Staphylococcus pasteurii) and a fungus (Engyotontium album), whereas Shivaji et al. (2006) identified four novel species of Bacillus, Bacillus aerius, B. aerophilus, B. stratosphericus and $B$. altitudinis, from cryogenic tubes used to collect air samples at altitudes of 24, 28 and $41 \mathrm{~km}$.

In this paper, a polyphasic taxonomic approach was used to characterize 12 bacterial strains isolated from cryotubes that were used to collect air at altitudes of between 27 and $41 \mathrm{~km}$, during a balloon flight. Three of the 12 bacterial isolates, strains PVAS- $1^{\mathrm{T}}, \mathrm{B} 3 \mathrm{~W} 22^{\mathrm{T}}$ and $\mathrm{B} 8 \mathrm{~W} 22^{\mathrm{T}}$, represent three novel species of the genera Bacillus $\left(\mathrm{B} 3 \mathrm{~W} 22^{\mathrm{T}}\right.$ and B8W22 ${ }^{\mathrm{T}}$ ) and Janibacter $\left(\right.$ PVAS- ${ }^{\mathrm{T}}$ ). 


\section{Collection of air from $24 \mathrm{~km}$ and above}

The balloon with the cryosampler payload used for collecting high-altitude air samples (altitude 20-41.4 km) was launched on 20 April 2005 from the National Scientific Balloon Facility of the Tata Institute of Fundamental Research at Hyderabad, India. The cryogenic sampler, comprising a 16-cryoprobe assembly, is similar to one used previously (Wainwright et al., 2003; Shivaji et al., 2006). All 16 cryosampling tubes were autoclaved at $120{ }^{\circ} \mathrm{C}$ for $4 \mathrm{~h}$ and integrated into the payload in a tissue-culture laboratory which was UV-sterilized overnight. The cryotubes were also checked for sterility after the assembly. For this purpose, three cryotubes were disconnected from the assembly, opened in a laminar flow hood, rinsed with sterile phosphate buffer (0.1 M, pH 7.2) and plated on Luria-Bertani (LB) agar and incubated at $37{ }^{\circ} \mathrm{C}$. No colonies had appeared after 1 month, indicating that the cryotubes were sterile. Therefore, the isolates reported in Table 1 should have originated from the air samples collected at the given altitudes. Cryotubes 1, 3, 5, 7, 9, 12, 13 and 15 were examined at the Centre for Cellular and Molecular Biology, Hyderabad, while cryotubes 2, 4, 6, 8, 10 and 14 were similarly studied at the National Centre for Cell Sciences, Pune. Care was taken that the two laboratories followed similar protocols, and there was frequent interaction and discussion between the two groups to ensure homogeneity of procedures and interpretation.

\section{Detection of viable bacteria from air collected in the cryotubes}

All the work related to detection of microbes in air samples from the cryotubes was carried out in a room with very little human traffic and inside a laminar flow hood available exclusively for the handling of the probes. The probes were transferred to the laminar flow hood one at a time and, prior to the transfer, the surface of the cryotubes was cleaned and sterilized with alcohol. All instruments used to unscrew the outlet valve of the cryotube such as spanners and screwdrivers were surface-sterilized with alcohol and flame-heated prior to use. The outlet valve of the cryotube was then connected to a series of two Millipore filtration units using sterile tubing and the air was sequentially filtered through a $0.45 \mu \mathrm{m}$ filter (Millipore cat. no. HAWP 04700 ) and a $0.22 \mu \mathrm{m}$ filter (Millipore cat. no. GSWP 04700) under aseptic conditions in the laminar flow hood. The $0.45 \mu \mathrm{m}$ and $0.22 \mu \mathrm{m}$ filters were then used for detection of bacteria. For this purpose, each filter was cut into quarters and one of the quarters was transferred to a nutrient agar plate $(0.5 \%$ peptone, $0.3 \%$ beef extract, $0.5 \% \mathrm{NaCl}$ and $1.5 \%$ agar, w/v) and incubated at $15{ }^{\circ} \mathrm{C}$. After about 10 days, if no growth was observed, the filter was transferred to an LB agar plate (1\% tryptone, $0.5 \%$ yeast extract, $1.0 \% \mathrm{NaCl}$ and $2.0 \%$ agar, $\mathrm{w} / \mathrm{v} ; \mathrm{pH} 7.2)$ or an oligotrophic LB agar plate (1/10 LB) and incubated at $15{ }^{\circ} \mathrm{C}$ for a further 15 days. Subsequently, if no colonies

Table 1. Bacteria isolated from cryotubes used for collecting air at altitudes of $20-41.4 \mathrm{~km}$

With the exception of strain PVAS- $1^{\mathrm{T}}$, which was isolated from an air sample, all the strains were isolated from washes of the cryotubes.

\begin{tabular}{|c|c|c|c|c|c|c|c|}
\hline \multirow[t]{2}{*}{ Cryotube } & \multirow{2}{*}{$\begin{array}{c}\text { Altitude } \\
(\mathbf{k m})\end{array}$} & \multirow{2}{*}{$\begin{array}{c}\text { Temperature } \\
\left({ }^{\circ} \mathrm{C}\right)\end{array}$} & \multirow{2}{*}{$\begin{array}{c}\text { Air } \\
\text { mass }(g)\end{array}$} & \multicolumn{4}{|c|}{ Isolated bacteria } \\
\hline & & & & Strain & Nearest phylogenetic neighbour & $\begin{array}{c}\text { Accession } \\
\text { no. }\end{array}$ & $\begin{array}{l}\text { 16S rRNA gene } \\
\text { sequence } \\
\text { similarity (\%) }\end{array}$ \\
\hline 1 & $20-24$ & -50 & 140 & None & - & & - \\
\hline 2 & $40-41.4$ & -20 & & None & - & & - \\
\hline 3 & $24-27$ & -40 & 65 & None & - & & - \\
\hline 4 & $24-27$ & -40 & & PVAS-8 & Stenotrophomonas rhizophila e-p $10^{\mathrm{T}}$ & AJ293463 & 99.0 \\
\hline 5 & $27-30$ & -35 & 55 & $\mathrm{~B} 3 \mathrm{~W} 22^{\mathrm{T}}$ & Bacillus silvestris $\mathrm{HR} 3-23^{\mathrm{T}}$ & AJ006086 & 99.5 \\
\hline 6 & $27-30$ & -35 & 55 & None & - & & - \\
\hline 7 & $30-35$ & -25 & 25 & None & - & & - \\
\hline 8 & $30-35$ & -25 & & PVAS-4 & Acinetobacter radioresistens BA50 & FJ263931 & 100.0 \\
\hline \multirow[t]{2}{*}{9} & $35-40$ & -20 & 13 & B5W22-1 & Micrococcus flavus $\mathrm{LW} 4^{\mathrm{T}}$ & DQ491453 & 99.2 \\
\hline & & & & B5W22-2 & Streptomyces maritimus $\mathrm{BD} 26^{\mathrm{T}}$ & AF233338 & 99.0 \\
\hline \multirow[t]{3}{*}{10} & $35-40$ & -20 & & PVAS-5 & Stenotrophomonas rhizophila e-p $10^{\mathrm{T}}$ & AJ293463 & 99.2 \\
\hline & & & & PVAS-6 & Acinetobacter calcoaceticus MTCC 9488 & FM210755 & 99.0 \\
\hline & & & & PVAS-10 & Bacillus pumilus BSH-4 & EF488975 & 99.0 \\
\hline \multirow[t]{3}{*}{11} & $40-41.4$ & -20 & & PVAS- $1^{\mathrm{T}}$ & Janibacter anophelis CCUG $49715^{\mathrm{T}}$ & AY837752 & 98.0 \\
\hline & & & & PVAS-2 & Methylobacterium chloromethanicum $\mathrm{CM} 4^{\mathrm{T}}$ & СР001298 & 99.0 \\
\hline & & & & PVAS-3 & Methylobacterium chloromethanicum $\mathrm{CM} 4^{\mathrm{T}}$ & СР001298 & 99.0 \\
\hline $12,13,15$ & $40-41.4$ & -20 & 2.5 & $\mathrm{~B} 8 \mathrm{~W} 22^{\mathrm{T}}$ & Bacillus megaterium IAM $13418^{\mathrm{T}}$ & D16273 & 99.7 \\
\hline 14 & $40-41.4$ & -20 & - & None & - & & - \\
\hline
\end{tabular}


appeared, the filters were incubated on LB agar at $25{ }^{\circ} \mathrm{C}$ for up to a month. It should be noted that, when hydrophobic $0.45 \mu \mathrm{m}$ (Millipore cat. no. HVHP 04700) and $0.22 \mu \mathrm{m}$ (cat. no. GVHP 04700) filters were used for filtering the air, a thin layer of medium of the same composition was applied to the surface of the plates before the filters were placed on the surface of the medium.

Two of the remaining quarters of the filter were transferred to minimal salts agar. This medium contained (per $100 \mathrm{ml}$ ) $20 \mathrm{ml}$ of a $3.39 \%(\mathrm{w} / \mathrm{v})$ sodium dihydrogen phosphate solution, $20 \mathrm{ml} 1.5 \%(\mathrm{w} / \mathrm{v})$ potassium phosphate, $20 \mathrm{ml}$ $0.25 \%(\mathrm{w} / \mathrm{v}) \mathrm{NaCl}, 20 \mathrm{ml} 0.5 \%$ (w/v) ammonium chloride and $18 \mathrm{ml}$ Millipore water. The final concentration of agar was $2 \%$. The medium was also supplemented with $2 \mathrm{ml}$ sterile $20 \%$ glucose and $0.2 \mathrm{ml}$ sterile $0.1 \mathrm{M} \mathrm{MgSO}_{4}$ solution; the $\mathrm{pH}$ was adjusted to 7 . This medium was used for the cultivation of organisms which require low nutrients. Blood agar $[2.3 \%(\mathrm{w} / \mathrm{v})$ peptone, $0.1 \%(\mathrm{w} / \mathrm{v})$ corn starch, $0.5 \%(\mathrm{w} / \mathrm{v}) \mathrm{NaCl}$ and $1.5 \%(\mathrm{w} / \mathrm{v})$ agar, to which $5 \%(\mathrm{v} / \mathrm{v})$ defibrinated blood was added (after autoclaving and cooling the medium)] was used for the cultivation of organisms which require rich media. Plates of minimal salt agar and blood agar were incubated at $30{ }^{\circ} \mathrm{C}$. One quarter of the filter was also incubated at $30{ }^{\circ} \mathrm{C}$ on Sabouraud agar (1.0\% enzymic digest of casein, $4 \%$ glucose and $1.5 \%$ agar, w/v) to facilitate fungal growth (data not shown).

Of the 15 cryotubes from which air was sampled, only a single novel bacterial colony was detected, in cryotube 11, corresponding to air collected at an altitude of 40-41.4 km (Table 1). When placed on minimal salts agar, the filter paper from cryotube 11 showed a single cream-coloured colony after 24 days of incubation at $30^{\circ} \mathrm{C}$, and it was designated strain PVAS $-1^{\mathrm{T}}$.

During the filtration process, plates containing fungal and bacterial media were left open in the laminar flow hood throughout the operation to check the sterility of the hood. These plates were incubated at $25{ }^{\circ} \mathrm{C}$ (for fungi) or $37{ }^{\circ} \mathrm{C}$ (bacteria) for 7 days prior to use, to confirm the sterility of the plates. Colonies were not detected on any of these plates, indicating that the sampling was done under sterile conditions.

\section{Detection of viable bacteria from washes of empty cryotubes}

It seemed possible that some bacteria might have remained at the bottom of the tubes or attached to their polished walls and thus escaped detection. To check this possibility, all 15 empty cryotubes were injected with $200 \mathrm{ml}$ sterile phosphate buffer $(0.1 \mathrm{M}, \mathrm{pH} 7.2)$ and agitated at $22{ }^{\circ} \mathrm{C}$ for $6 \mathrm{~h}$ in a shaker. The liquid was then removed using sterile tubing and a syringe and filtered through a $0.22 \mu \mathrm{m}$ Millipore filter ( $47 \mathrm{~mm}$ diameter). These filters were each cut aseptically into four sectors and each sector was placed on a plate containing one of four different media, LB agar, minimal salts agar, blood agar and Sabouraud agar, and incubated under the conditions described above. The plates were observed for the appearance of colonies over a period of 1 month.

From the 15 cryotube wash samples, 12 bacterial colonies were detected (Table 1). Nine (PVAS-2, $-3,-4,-5,-6,-8$ and -10 and B5W22-1 and B5W22-2) showed more than $98 \% 16 \mathrm{~S}$ rRNA gene sequence similarity to reported species (Table 1). Therefore, further attempts were not made to characterize them to the species level.

\section{Morphological, biochemical and chemotaxonomic characteristics}

Morphological, growth and biochemical studies of viable colonies were performed using standard methods (Holding \& Collee, 1971; Smibert \& Krieg, 1994). LB agar was used for growth and maintenance and for the determination of phenotypic and chemotaxonomic characteristics of all strains except PVAS-2 and -3. Strains PVAS-2 and -3 were grown on a medium containing $0.25 \%(\mathrm{w} / \mathrm{v}) \mathrm{K}_{2} \mathrm{HPO}_{4}$, $0.225 \%(\mathrm{w} / \mathrm{v}) \mathrm{NaH}_{2} \mathrm{PO}_{4}, 0.05 \%(\mathrm{w} / \mathrm{v})\left(\mathrm{NH}_{4}\right)_{2} \mathrm{SO}_{4}, 0.02 \%$ (w/v) $\mathrm{MgSO}_{4} \cdot 7 \mathrm{H}_{2} \mathrm{O}$ and $0.1 \%$ (v/v) methanol. The shape, size and motility of the strains were ascertained using a Leitz Diaplan phase-contrast microscope with an oilimmersion objective $(\times 100)$. The sensitivity of the cultures to antibiotics was determined by using antibiotic discs (HiMedia). Utilization of various carbon compounds as sole carbon sources was tested in mineral liquid medium supplemented with $0.2 \%$ filter-sterilized carbon source as described previously (Shivaji et al., 2006). Fatty acid and lipid composition (Sato \& Murata, 1988; Kiran et al., 2004), DNA G + C content (Shivaji et al., 1992, 2005) and DNA-DNA hybridization (Tourova \& Antonov, 1987; Shivaji et al., 1992) were determined according to standard procedures. Analyses of polar lipids, respiratory quinones and meso-diaminopimelic for PVAS- $1^{\mathrm{T}}$ were carried out by the Identification Service of the DSMZ (Braunschweig, Germany). Isoprenoid quinones were also extracted according to the method of Collins et al. (1977), separated by HPLC and identified as described previously (Reddy et al., 2003). Peptidoglycan was prepared and analysed according to the method described by Komagata \& Suzuki (1987).

Detailed phenotypic and chemotaxonomic characteristics (listed in Tables 2, 3 and 4 and in the species descriptions) were compared with those of Bacillus silvestris DSM $12223^{\mathrm{T}}$, Bacillus megaterium MTCC $428^{\mathrm{T}}$, Janibacter anophelis CCUG $49715^{\mathrm{T}}$, Janibacter terrae DSM $13876^{\mathrm{T}}$, Janibacter melonis DSM $16063^{\mathrm{T}}$, Janibacter limosus DSM $11140^{\mathrm{T}}$ and Janibacter corallicola DSM $18906^{\mathrm{T}}$.

Cells of strain PVAS- $1^{\mathrm{T}}$ are Gram-positive, coccoid, nonendospore-forming and non-motile and occur singly or in clumps. Some biochemical characteristics are listed in Table 2. meso-Diaminopimelic acid is the diagnostic diamino acid in the cell-wall peptidoglycan and iso- $\mathrm{C}_{16: 0}$ 
Table 2. Physiological properties that differentiate strain PVAS $-1^{\top}$ and the type strains of other species of the genus Janibacter

Strains: 1, Janibacter hoylei sp. nov. PVAS $-1^{\mathrm{T}}$ (data from this study); 2, Janibacter anophelis DSM $18333^{\mathrm{T}} ; 3$, Janibacter terrae DSM $13876^{\mathrm{T}}$; 4, Janibacter limosus DSM $11140^{\mathrm{T}}$ (unless indicated, data in columns 2-4 from Kämpfer et al., 2006); 5, Janibacter melonis DSM $16063^{\mathrm{T}}$ (Yoon et al., 2004); 6, Janibacter corallicola DSM $18906^{\mathrm{T}}$ (Kageyama et al., 2007). All strains were negative for growth at $40{ }^{\circ} \mathrm{C}$, utilization of $\mathrm{N}$-acetylglutamic acid, haemolysis, motility, methyl red test and $\mathrm{H}_{2} \mathrm{~S}$ production and positive for catalase, starch hydrolysis and gelatin hydrolysis. All strains tolerate up to $6 \% \mathrm{NaCl}$ +, Positive; -, negative; w, weakly positive; $\mathrm{d}$, delayed reaction; TSBA, tryptic soy broth agar; CASO agar, casein-peptone-soymeal peptone agar.

\begin{tabular}{|c|c|c|c|c|c|c|}
\hline Characteristic & 1 & 2 & 3 & 4 & 5 & 6 \\
\hline Growth at $37^{\circ} \mathrm{C}$ on TSBA & + & + & $\mathrm{w}$ & - & + & + \\
\hline Growth at $37^{\circ} \mathrm{C}$ on CASO agar ${ }^{*}$ & + & $\mathrm{W}$ & + & - & + & - \\
\hline \multicolumn{7}{|l|}{ Growth with $\mathrm{NaCl}$ at: } \\
\hline $8 \% *$ & + & + & + & + & - & + \\
\hline $10 \%^{*}$ & + & + & $\mathrm{w}$ & $\mathrm{w}$ & - & + \\
\hline \multicolumn{7}{|l|}{ Utilization of: } \\
\hline D-Malate & - & - & $\mathrm{w}$ & + & $\mathrm{w}$ & + \\
\hline Sodium benzoate ${ }^{*}$ & - & - & + & + & $\mathrm{w}$ & $\mathrm{w}$ \\
\hline Sodium citrate ch $^{\star}$ & - & - & - & - & $\mathrm{w}$ & - \\
\hline Sodium formate ${ }^{\star}$ & - & - & $\mathrm{w}$ & - & $\mathrm{w}$ & - \\
\hline Sodium succinate ${ }^{*}$ & - & - & $\mathrm{w}$ & $\mathrm{w}$ & $\mathrm{w}$ & + \\
\hline D-Gluconate & - & + & + & + & - & + \\
\hline D-Glucose & - & + & + & + & $\mathrm{w}$ & - \\
\hline Inositol & - & + & + & $\mathrm{w}$ & - & + \\
\hline Maltose & - & + & $\mathrm{d}$ & + & $\mathrm{w}$ & + \\
\hline D-Mannose & - & + & + & $\mathrm{w}$ & $\mathrm{w}$ & + \\
\hline Monomethyl succinate & + & - & $\mathrm{W}$ & + & - & - \\
\hline Putrescine & - & - & + & + & - & - \\
\hline Sucrose & - & + & + & + & $\mathrm{w}$ & + \\
\hline Trehalose & - & + & $\mathrm{d}$ & + & + & - \\
\hline D-Galactose & - & - & - & - & + & + \\
\hline Casein ${ }^{\star}$ & + & + & + & + & - & - \\
\hline Tween $80^{*}$ & - & + & - & - & + & - \\
\hline Aesculin* & - & - & - & $\mathrm{w}$ & + & - \\
\hline Voges-Proskauer reaction ${ }^{*}$ & $\mathrm{w}$ & - & + & $\mathrm{w}$ & + & - \\
\hline
\end{tabular}

${ }^{\star}$ Data generated for this study by the Identification Services of the DSMZ.

(50.4\%), iso- $\mathrm{C}_{18: 0}$ (5.1\%), 10-methyl $\mathrm{C}_{17: 0} \quad(10.9 \%)$, $\mathrm{C}_{17: 1} \Delta 9 c(12.1 \%)$ and $\mathrm{C}_{18: 1} \Delta 9 c(6.0 \%)$ are the predominant fatty acids. Mycolic acids are absent. The predominant isoprenoid quinone present is MK- $8\left(\mathrm{H}_{4}\right)$. The DNA $\mathrm{G}+\mathrm{C}$ content is $72.8 \mathrm{~mol} \%$. These characteristics and phylogenetic analysis of the 16S rRNA gene sequence indicated that PVAS- $1^{\mathrm{T}}$ is a member of the genus Janibacter.

Cells of strains $\mathrm{B} 3 \mathrm{~W} 22^{\mathrm{T}}$ and $\mathrm{B} 8 \mathrm{~W} 22^{\mathrm{T}}$ are Gram-positive, rod-shaped, endospore-forming and catalase-positive, with $\mathrm{C}_{15: 0}, \mathrm{C}_{16: 0}$, iso- $\mathrm{C}_{15: 0}$, anteiso- $\mathrm{C}_{14: 0}$, anteiso- $\mathrm{C}_{16: 0}$ and
$\mathrm{C}_{16: 1} \Delta 9 c$ as the predominant fatty acids (Tables 3 and 4 ). The polar lipid profile of strain $\mathrm{B} 3 \mathrm{~W} 22^{\mathrm{T}}$ contains phosphatidylglycerol (PG), phosphatidylethanolamine (PE), phosphatidylserine (PS) and one unidentified lipid, whereas that of strain B8W $22^{\mathrm{T}}$ has only PG and PE. MK-6, MK-7 and MK-8 are the menaquinones in strain B3W22 ${ }^{\mathrm{T}}$ whereas, in $\mathrm{B} 8 \mathrm{~W} 22^{\mathrm{T}}$, only MK-7 was present (Table 3 ). The DNA G+C contents of the two strains are 38$40 \mathrm{~mol} \%$. These characteristics indicated that strains $\mathrm{B} 3 \mathrm{~W} 22^{\mathrm{T}}$ and $\mathrm{B} 8 \mathrm{~W} 22^{\mathrm{T}}$ are members of the genus Bacillus (Tables 3 and 4).

\section{Phylogenetic analysis}

The 16S rRNA gene was amplified from genomic DNA, purified and sequenced as described previously (Shivaji et al., 2000; Pidiyar et al., 2004). To ascertain the phylogenetic affiliation of the novel strains, the almost-complete $16 \mathrm{~S}$ rRNA gene sequences of the bacterial isolates were manually corrected and aligned using CLUSTAL_X (Thompson et al., 1994). Phylogenetic trees were constructed based on neighbour-joining (Saitou \& Nei, 1987) and maximumparsimony methods using MEGA 3.1 (Kumar et al., 2004). Evolutionary distances were determined with Kimura's twoparameter model (Kimura, 1980). Bootstrap analysis (Felsenstein, 1993) was performed for 1000 replications. Reference sequences were retrieved from GenBank under the accession numbers indicated on the trees.

Phylogenetic analysis of the 16S rRNA gene sequence of strain PVAS- $1^{\mathrm{T}}$ (1196 bp) indicated that its closest relatives were Janibacter anophelis CCUG $49715^{\mathrm{T}}$ (98\% similarity) and Janibacter terrae DSM $13953^{\mathrm{T}}(98 \%)$ (Lang et al., 2003). Both the neighbour-joining tree (Fig. 1) and the maximum-parsimony tree (not shown) revealed that strain PVAS $-1^{\mathrm{T}}$ clustered most closely with these strains. DNADNA relatedness of PVAS- $1^{\mathrm{T}}$ with Janibacter terrae DSM $13953^{\mathrm{T}}$ was $29.8 \%$ and with Janibacter anophelis DSM $18333^{\mathrm{T}}$ was $13.7 \%$, and the reciprocal reactions in both cases gave values of about $9-10 \%$. Thus, strain PVAS $-1^{\mathrm{T}}$ represents a novel species of the genus Janibacter, for which the name Janibacter hoylei sp. nov. is proposed.

Strains $\mathrm{B} 3 \mathrm{~W} 22^{\mathrm{T}}$ and $\mathrm{B} 8 \mathrm{~W} 22^{\mathrm{T}}$ are related at the $16 \mathrm{~S}$ rRNA gene sequence level ( $91 \%$ similarity), but the sequences differ by more than $2.5 \%$, indicating that they probably represent different species. BLASTN analysis indicated that the nearest phylogenetic neighbour of $\mathrm{B} 3 \mathrm{~W} 22^{\mathrm{T}}$ is Bacillus silvestris $\mathrm{H} 3-23^{\mathrm{T}}$ ( $99.5 \%$ similarity), with which it forms a clade in the phylogenetic tree, and it is separated from Caryophanon latum DSM $14151^{\mathrm{T}}$ and Caryophanon tenue DSM $14152^{\mathrm{T}}$, with which it exhibits about 97 and $96 \%$ similarity, respectively (Fig. 2). The members of the genus Caryophanon are characterized by the presence of slightly curved to straight trichomes, and are thus clearly different from $\mathrm{B} 3 \mathrm{~W} 22^{\mathrm{T}}$.

DNA-DNA hybridization studies indicated that the relatedness between $\mathrm{B} 3 \mathrm{~W} 22^{\mathrm{T}}$ and Bacillus silvestris DSM 
$12223^{\mathrm{T}}$ is only $29 \%$ (reciprocal reaction $37 \%$ ). Furthermore, these two strains exhibit phenotypic and chemotaxonomic differences (Tables 3 and 4) that imply that $\mathrm{B} 3 \mathrm{~W} 22^{\mathrm{T}}$ represents a novel species; the name proposed is Bacillus isronensis sp. nov.

In the phylogenetic tree, strain $\mathrm{B} 8 \mathrm{~W} 22^{\mathrm{T}}$ forms a robust clade with its nearest phylogenetic neighbour Bacillus megaterium IAM $13418^{\mathrm{T}}$ (Fig. 2), with which it shows $99.7 \%$ similarity at the $16 \mathrm{~S}$ rRNA gene sequence level. Despite this high similarity, it is observed that, at the whole genome level, the DNA-DNA relatedness between B8W22 and Bacillus megaterium MTCC $428^{\mathrm{T}}$ is only $35 \%$ (reciprocal reaction $43 \%$ ), indicating that $\mathrm{B} 8 \mathrm{~W} 22^{\mathrm{T}}$ could be assigned to a novel species. Furthermore, $\mathrm{B} 8 \mathrm{~W} 22^{\mathrm{T}}$ and Bacillus megaterium MTCC $428^{\mathrm{T}}$ differ in their phenotypic and chemotaxonomic characteristics (Tables 3 and 4), implying that $\mathrm{B} 8 \mathrm{~W} 22^{\mathrm{T}}$ does indeed represent a novel species, for which the name proposed is Bacillus aryabhattai sp. nov. Similarity of B8W $22^{\mathrm{T}}$ to other Bacillus species at the $16 \mathrm{~S}$ rRNA gene sequence level was less than $95 \%$.

\section{Sensitivity to UV radiation}

Cultures were grown to an $\mathrm{OD}_{660}$ of 1.0 at $30{ }^{\circ} \mathrm{C}$ and the sensitivity to UV radiation was determined by exposure to a UV lamp (UV-B, 15 W64; Sankyo Denki) as described previously (Shivaji et al., 2006). Cultures of Bacillus silvestris DSM $12223^{\mathrm{T}}$, Bacillus megaterium MTCC $428^{\mathrm{T}}$, Micrococcus luteus MTCC $106^{\mathrm{T}}$, Janibacter limosus DSM $11140^{\mathrm{T}}$ and Janibacter terrae DSM $13876^{\mathrm{T}}$ were used as controls in these experiments. The results indicate that strains $\mathrm{B} 3 \mathrm{~W} 22^{\mathrm{T}}, \mathrm{B} 8 \mathrm{~W} 22^{\mathrm{T}}$ and PVAS- $1^{\mathrm{T}}$ are more resistant to UV irradiation than their nearest phylogenetic neighbours (Supplementary Table S1, available in IJSEM Online).

\section{Conclusions}

The bacterial strains identified are unlikely to be laboratory contaminants, because no such cultures were handled in the laboratory. The control plates that were exposed to the air flow of the laminar flow hood during the entire air filtration procedure did not show any colonies. Furthermore, all possible precautions were taken to rule out contamination of the cryotubes throughout the assembly and deployment stages of the experiment; it is unlikely that they came from the cryotube assembly facility and survived the transit through the stratosphere, because the control cryotubes were completely sterile. It has been argued that micro-organisms can travel across interplanetary space during routine meteoritic exchanges between the Earth and Mars (Gladman et al., 1996; Mileikowsky et al. 2000; Nicholson et al., 2000). Furthermore, it is possible that micro-organisms reach the stratosphere from the Earth as a result of volcanic eruptions, the updraft caused by blue lightning strikes (Pasko et al., 2002), thunderstorms and forest fires (Fromm et al., 2004) and gravitophotophoresis (Rohatschek, 1996). Finally, in 1982, Hoyle and Wickramasinghe proposed the theory of 'Panspermia' (Hoyle \& Wickramasinghe, 1986, 1993, 1999).

\section{Description of Janibacter hoylei sp. nov.}

Janibacter hoylei (hoy'le.i. N.L. gen. n. hoylei of Hoyle, named after Sir Fred Hoyle, the famous English astronomer).

Colonies on LB agar are creamish, entire, round and 1$2 \mathrm{~mm}$ in diameter. Cells stain Gram-positive and show oxidative metabolism; they are non-motile, non-endospore-forming cocci, $0.4-0.7 \mu \mathrm{m}$ in diameter, that occur singly or in clumps. Good growth (visible colonies with a diameter of $1 \mathrm{~mm}$ ) occurs after 2 days of incubation on nutrient agar at $25-30{ }^{\circ} \mathrm{C}$. Grows in LB broth at $20-40{ }^{\circ} \mathrm{C}$ and at $\mathrm{pH} 5-10$, with optimum growth at $30^{\circ} \mathrm{C}$ and $\mathrm{pH} 9$. Grows in the presence of $5 \%(\mathrm{w} / \mathrm{v}) \mathrm{NaCl}$ in $\mathrm{LB}$ broth and exhibits weak growth in LB broth containing $10 \% \mathrm{NaCl}$. Resistant to UV radiation. Catalase- and oxidase-positive; $\mathrm{H}_{2} \mathrm{~S}$ is not produced. Voges-Proskauer negative, indolenegative and reduces nitrate to nitrite. Results of carbon source utilization tests are shown in Table 2. Does not produce acid from alcohols or the following sugars: Dglucose, D-fructose, D-galactose, lactose, maltose, cellobiose, D-mannitol, D-mannose, raffinose, L-rhamnose, D-ribose, D-sorbitol, trehalose and D-xylose. mesoDiaminopimelic acid is the diagnostic diamino acid in the cell-wall peptidoglycan. The main fatty acids present are iso- $\mathrm{C}_{16: 0}, 10$-methyl $\mathrm{C}_{17: 0}, \mathrm{C}_{18: 1} \Delta 9 c$ and $\mathrm{C}_{17: 1} \Delta 9 c$. The predominant isoprenoid quinone present is $\mathrm{MK}-8\left(\mathrm{H}_{4}\right)$. In whole-cell hydrolysates, ribose and glucose are present, but arabinose, galactose and mannose are absent. Mycolic acids are absent. The DNA base composition of the type strain is $72.8 \mathrm{~mol} \% \mathrm{G}+\mathrm{C}$.

The type strain is PVAS $-1^{\mathrm{T}}\left(=\right.$ MTCC $8307^{\mathrm{T}}=$ DSM $21601^{\mathrm{T}}=$ CCUG $\left.56714^{\mathrm{T}}\right)$, isolated from an air sample collected at an altitude of $40-41.4 \mathrm{~km}$ using a cryosampler.

\section{Description of Bacillus isronensis sp. nov.}

Bacillus isronensis (is.ro.nen'sis. N.L. masc. adj. isronensis arbitrary name pertaining to ISRO, the acronym of the Indian Space Research Organization, which largely funded the studies in which the type strain was isolated).

Colonies on nutrient agar are white, entire, round and 3$4 \mathrm{~mm}$ in diameter. Cells produce round terminal endospores and are motile. Grows at $5-37{ }^{\circ} \mathrm{C}$ and $\mathrm{pH}$ 6-10. Does not grow at $42{ }^{\circ} \mathrm{C}$ or at $\mathrm{pH} 4$ or 11 . Tolerates up to $5.8 \% \mathrm{NaCl}$. Resistant to UV radiation. Grows on peptone. Positive for oxidase, lipase, gelatinase, starch hydrolysis, caseinase, tryptophan deamination, nitrate reduction and indole production. Produces acid from cellobiose and utilizes a number of sugars, amino acids and other carbon compounds as sole carbon sources 
Table 3. Physiological properties that differentiate strains $B 3 W 22^{\top}$ and $B 8 W 22^{\top}$ and their nearest phylogenetic neighbours

Strains: 1, Bacillus isronensis sp. nov. B3W22 $2^{\mathrm{T}} ; 2$, Bacillus silvestris DSM $12223^{\mathrm{T}} ; 3$, Bacillus aryabhattai sp. nov. B8W22 ${ }^{\mathrm{T}} ; 4$, Bacillus megaterium MTCC $428^{\mathrm{T}}$. All four strains have Gram-positive, motile, rod-shaped cells that produce endospores, grow at $20-37{ }^{\circ} \mathrm{C}$ and $\mathrm{pH} 6-10$, tolerate $5.8 \%$ $\mathrm{NaCl}$ and grow in peptone broth and are positive for catalase and $\beta$-galactosidase but do not grow at $\mathrm{pH} 4$ or 11 and are negative for citrate utilization, the methyl red test and $\mathrm{H}_{2} \mathrm{~S}$ production. None of the strains produces acid from sucrose or inulin or uses dextran, citric acid, cellulose, glycogen, thioglycolate, hydroxybutyric acid, salicin, D-glucuronic acid, L-aspartic acid, sodium succinate, valeric acid, L-cysteine, L-tyrosine, Lphenylalanine, L-proline or L-histidine as sole carbon sources. All four strains utilize glycerol, myo-inositol, methyl $\alpha$-D-galactoside, L-ornithine and $\mathrm{L}$-creatinine as sole carbon sources, are resistant to discs containing colistin $(10 \mu \mathrm{g})$ and are sensitive to discs containing norflaxacin (10 $\mu \mathrm{g})$, tobramycin $(15 \mu \mathrm{g})$, lomefloxacin $(30 \mu \mathrm{g})$, amikacin $(30 \mu \mathrm{g})$, roxithromycin $(15 \mu \mathrm{g})$, ciprofloxacin $(30 \mu \mathrm{g})$, nitrofurantoin $(300 \mu \mathrm{g})$, cefoperazone $(75 \mu \mathrm{g})$, vancomycin $(30 \mu \mathrm{g})$, lincomycin $(15 \mu \mathrm{g})$, cephotaxime $(30 \mu \mathrm{g})$, kanamycin $(30 \mu \mathrm{g})$, novobiocin $(30 \mu \mathrm{g})$, chloramphenicol $(30 \mu \mathrm{g})$, ampicillin $(25 \mu \mathrm{g})$, tetracycline $(30 \mu \mathrm{g})$, bacitracin $(10 \mu \mathrm{g})$, gentamicin $\mathrm{G}(30 \mu \mathrm{g})$, polymyxin $\mathrm{B}(50 \mu \mathrm{g})$, oleandomycin $(15 \mu \mathrm{g})$, spectinomycin $(100 \mu \mathrm{g})$, rifampicin $(30 \mu \mathrm{g})$, erythromycin $(15 \mu \mathrm{g})$ and carbenicillin $(100 \mu \mathrm{g}) .+$, Positive; -, negative; v, variable; w, weak; s, sensitive; $\mathrm{R}$, resistant.

\begin{tabular}{|c|c|c|c|c|}
\hline Characteristic & 1 & 2 & 3 & 4 \\
\hline Isolation source & Upper atmosphere & Forest soil & Upper atmosphere & Soil \\
\hline Colony diameter (mm) & $3-4$ & $3-4$ & $5-8$ & $6-8$ \\
\hline Colony colour & White & White & Peach & White/cream \\
\hline Endospores & Round, terminal & Round, terminal & Ellipsoidal, central & Ellipsoidal, central \\
\hline $10{ }^{\circ} \mathrm{C}$ & + & + & + & - \\
\hline $1.5 \mathrm{M} \mathrm{NaCl}$ & $\mathrm{V}$ & + & + & + \\
\hline $2 \mathrm{M} \mathrm{NaCl}$ & - & + & + & + \\
\hline $2.5 \mathrm{M} \mathrm{NaCl}$ & - & + & - & + \\
\hline \multicolumn{5}{|l|}{ Temperature for growth $\left({ }^{\circ} \mathrm{C}\right)$} \\
\hline Optimum & 28 & $20-30$ & 28 & 37 \\
\hline Lipase (Tween 80 hydrolysis) & + & - & - & - \\
\hline Gelatinase & + & - & + & + \\
\hline Phosphatase & - & - & + & - \\
\hline Aesculin hydrolysis & - & - & + & + \\
\hline Starch hydrolysis & + & - & + & + \\
\hline Lysine decarboxylase & - & - & + & + \\
\hline Arginine decarboxylase & - & - & - & + \\
\hline Arginine dihydrolase & - & - & - & + \\
\hline Caseinase & + & - & + & + \\
\hline Tryptophan deamination & + & - & + & - \\
\hline Reduction of nitrate to nitrite & + & - & + & + \\
\hline Indole production & + & - & - & - \\
\hline $\begin{array}{l}\text { Trehalose, maltose, adonitol, erythritol, } \\
\text { mannose }\end{array}$ & - & - & + & - \\
\hline Rhamnose & - & - & - & + \\
\hline Cellobiose & + & - & + & + \\
\hline
\end{tabular}


Table 3. cont.

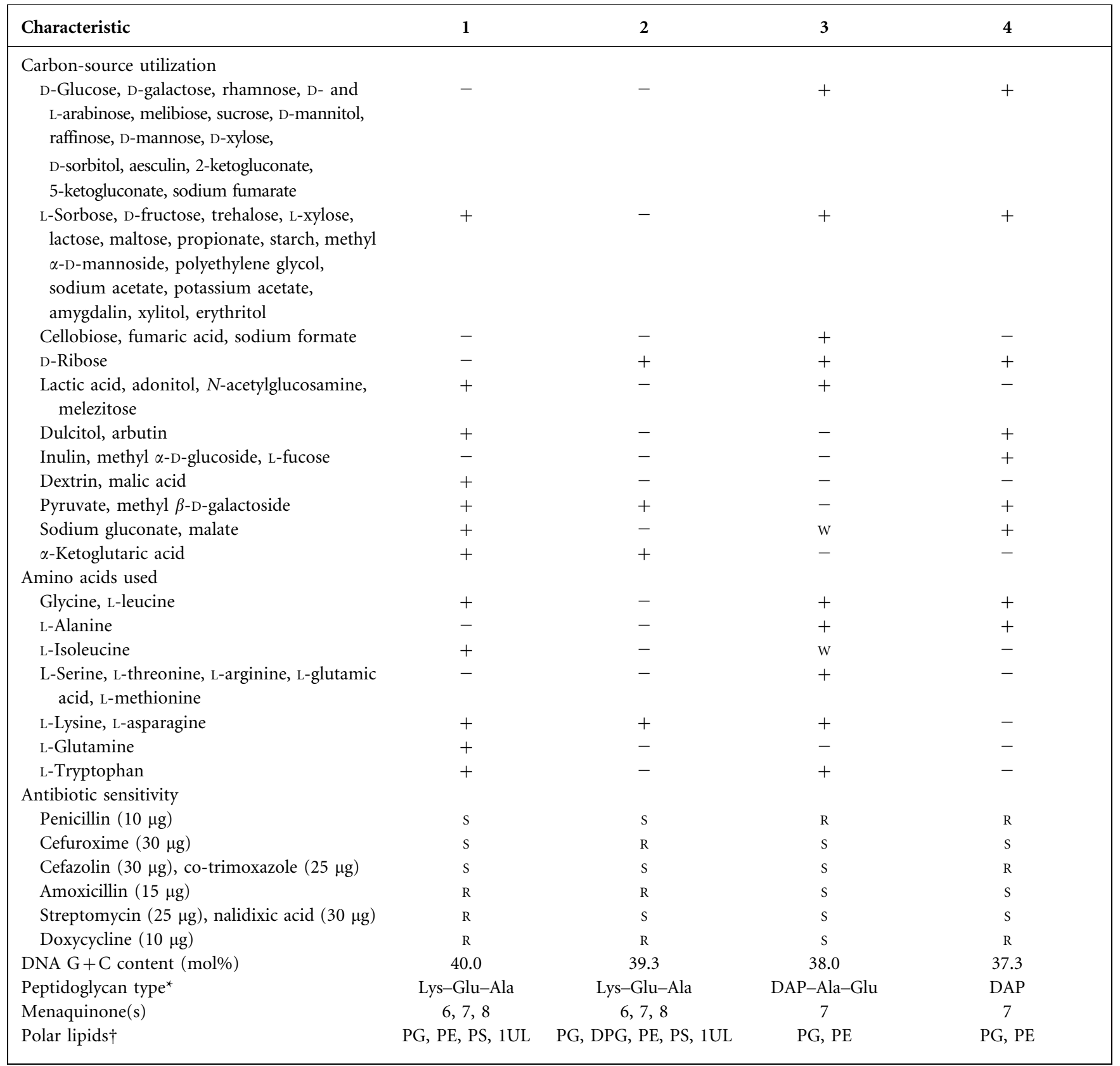

${ }^{*}$ DAP, Diaminopimelic acid.

†DPG, Diphosphatidylglycerol; PE, phosphatidylethanolamine; PG, phosphatidylglycerol; PS, phosphatidylserine; UL, unknown lipid.

(Table 3). The type strain is sensitive to a number of antibiotics (Table 3 ). The fatty acids present are $\mathrm{C}_{15: 0}$, $\mathrm{C}_{16: 0}, \mathrm{C}_{17: 0}$, iso- $\mathrm{C}_{13: 0}$, iso- $\mathrm{C}_{15: 0}$, anteiso- $\mathrm{C}_{14: 0}$, anteiso$\mathrm{C}_{16: 0}, \mathrm{C}_{16: 1} \Delta 9 c, \mathrm{C}_{16: 1} \Delta 11$ and $\mathrm{C}_{18: 1} \Delta 9$ (Table 4). The interpeptide bridge of the cell-wall peptidoglycan consists of Lys-Glu-Ala. The lipids present are PG, PE, PS and an unidentified lipid. MK-6, MK-7 and MK- 8 are the menaquinones present. The DNA $\mathrm{G}+\mathrm{C}$ content of the type strain is $40 \mathrm{~mol} \%$.
The type strain is $\mathrm{B} 3 \mathrm{~W} 22^{\mathrm{T}}$ (=MTCC $7902^{\mathrm{T}}=\mathrm{JCM}$ $13838^{\mathrm{T}}$ ), isolated from a cryogenic tube used for collecting an air sample from an altitude of $27-30 \mathrm{~km}$.

\section{Description of Bacillus aryabhattai sp. nov.}

Bacillus aryabhattai (a.ry.a.bhat' ta.i. N.L. gen. n. aryabhattai of Aryabhatta, named after the renowned Indian astronomer of the 5th century AD). 
Table 4. Total fatty acid compositions of strains $B 3 W 22^{\top}$ and $\mathrm{B} 8 \mathrm{~W} 22^{\top}$ and related type strains

Strains: 1, Bacillus isronensis sp. nov. $\mathrm{B} 3 \mathrm{~W} 22^{\mathrm{T}} ; 2$, Bacillus silvestris DSM $12223^{\mathrm{T}} ; 3$, Bacillus aryabhattai sp. nov. B8W22 ${ }^{\mathrm{T}} ; 4$, Bacillus megaterium MTCC $428^{\mathrm{T}}$. Data are percentages of total fatty acids and were obtained in this study; strains were grown on nutrient agar $(1 \%$ beef extract, $1 \%$ peptone, $0.5 \% \mathrm{NaCl}$ and $1.5 \%$ agar; $\mathrm{pH} 7.2)$ and incubated overnight at $30{ }^{\circ} \mathrm{C}$.

\begin{tabular}{|lcccc|}
\hline Fatty acid & $\mathbf{1}$ & $\mathbf{2}$ & $\mathbf{3}$ & $\mathbf{4}$ \\
\hline $\mathrm{C}_{12: 0}$ & 0 & 0 & 0 & 7.4 \\
$\mathrm{C}_{13: 0}$ & 0 & 0 & 0 & 1.0 \\
$\mathrm{C}_{14: 0}$ & 0 & 2.5 & 4.2 & 1.2 \\
$\mathrm{C}_{15: 0}$ & 51.5 & 57.6 & 46.2 & 5.2 \\
$\mathrm{C}_{16: 0}$ & 2.8 & 1 & 0 & 35.7 \\
$\mathrm{C}_{17: 0}$ & 4.5 & 3.3 & 0 & 0 \\
$\mathrm{C}_{18: 0}$ & 0 & 0 & 2.8 & 0 \\
iso- $\mathrm{C}_{13: 0}$ & 1.8 & 0 & 0 & 0 \\
iso- $\mathrm{C}_{15: 0}$ & 3.5 & 3.2 & 1.3 & 1.0 \\
anteiso- $\mathrm{C}_{14: 0}$ & 8.8 & 8.4 & 34.3 & 1.1 \\
anteiso- $\mathrm{C}_{16: 0}$ & 2.8 & 2.5 & 5.7 & 5.4 \\
$\mathrm{C}_{16: 1} \Delta 9 c$ & 19.8 & 21.5 & 4.7 & 13.8 \\
$\mathrm{C}_{16: 1} \Delta 11 c$ & 2.0 & 0 & 0 & 0 \\
$\mathrm{C}_{18: 1} \Delta 9 c$ & 2.5 & 0 & 0 & 2.1 \\
$\mathrm{C}_{18: 1} \Delta 11 c$ & 0 & 0 & 0 & 26.6 \\
\hline
\end{tabular}

Colonies on nutrient agar are peach-coloured, entire, round, flat and $5-8 \mathrm{~mm}$ in diameter. Cells produce ellipsoidal and central endospores and are motile. Growth occurs at $10-37^{\circ} \mathrm{C}$ and $\mathrm{pH} 6-10$. Does not grow at $42{ }^{\circ} \mathrm{C}$ or at $\mathrm{pH} 4$ or 11 . Tolerates up to $11.6 \% \mathrm{NaCl}$. Resistant to UV radiation. Grows on peptone. Positive for phosphatase, DNase, tryptophan deamination, ornithine decarboxylase and malonate utilization (Table 3). Produces acid from various carbon sources and utilizes a number of sugars, amino acids and other carbon compounds as sole

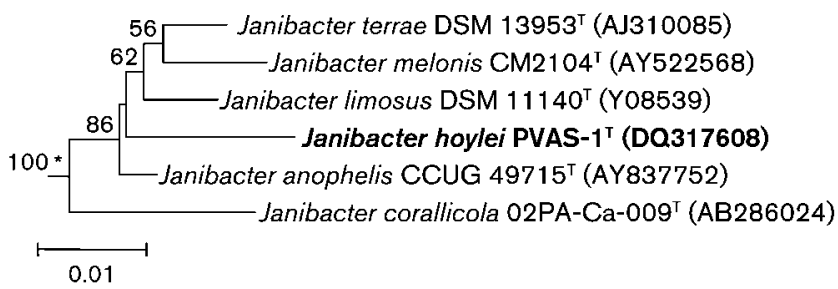

Fig. 1. Neighbour-joining phylogenetic tree reconstructed on the basis of $16 \mathrm{~S}$ rRNA gene sequences showing the phylogenetic relationships between strain PVAS $-1^{\top}$ and closely related species of the genus Janibacter. The sequence of Brevibacterium linens DSM $20425^{\top}$ (GenBank accession no. X77451; not shown) was used as an outgroup. Bootstrap values (expressed as percentages of 1000 replications) $>50 \%$ are given at nodes. Bar, 1 substitution per 100 nucleotide positions. The asterisk $\left(^{*}\right)$ indicates that this was the only branch point that was conserved in the parsimony analysis.

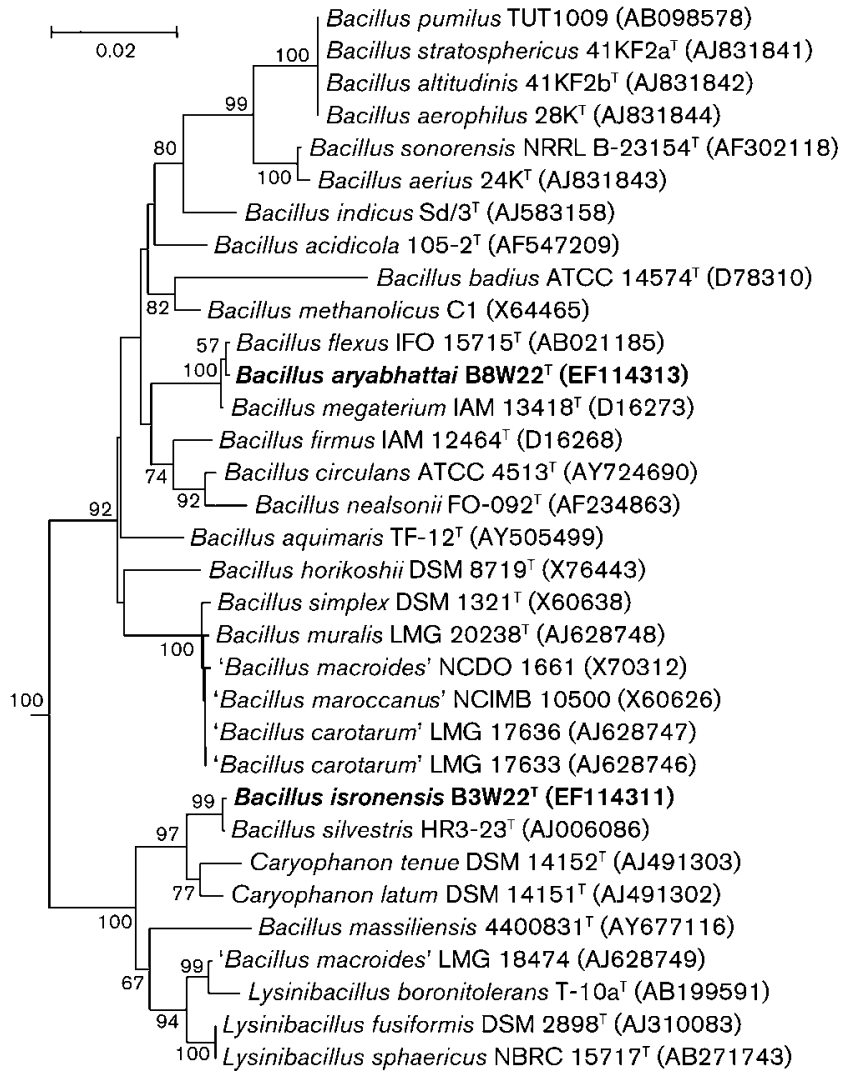

Fig. 2. Neighbour-joining phylogenetic tree reconstructed on the basis of $16 \mathrm{~S}$ rRNA gene sequences showing the phylogenetic relationships between strains $\mathrm{B} 3 \mathrm{~W} 22^{\top}$ and $\mathrm{B} 8 \mathrm{~W} 22^{\top}$ and closely related species of the genera Bacillus, Caryophanon and Lysinibacillus. The sequence of Microbacterium indicum DSM $20030^{\top}$ (GenBank accession no. AJ536198; not shown) was used as an outgroup. Bootstrap values (expressed as percentages of 1000 replications) $>50 \%$ are given at nodes. Bar, 2 substitutions per 100 nucleotide positions.

carbon sources (Table 3). The type strain is sensitive to a number of antibiotics (Table 3 ). The fatty acids present are $\mathrm{C}_{14: 0}, \mathrm{C}_{15: 0}, \mathrm{C}_{18: 0}$, iso- $\mathrm{C}_{15: 0}$, anteiso- $\mathrm{C}_{14: 0}$, anteiso- $\mathrm{C}_{16: 0}$ and $\mathrm{C}_{16: 1} \Delta 9 c$ (Table 4). The interpeptide bridge of the cellwall peptidoglycan consists of meso-diaminopimelic acidAla-Glu. The lipids present are PG and PE. MK-7 is the menaquinone present. The DNA G $+\mathrm{C}$ content of the type strain is $38 \mathrm{~mol} \%$.

The type strain is B $8622^{\mathrm{T}}\left(=\right.$ MTCC $\left.7755^{\mathrm{T}}=\mathrm{JCM} 13839^{\mathrm{T}}\right)$, isolated from a cryogenic tube used for collecting an air sample from an altitude of $40-41.4 \mathrm{~km}$.

\section{Acknowledgements}

The present study is part of a long-term study partly conceptualized and largely funded by the Indian Space Research Organization, Department of Space, Government of India. The payload environmental testing and some critical parameter evaluations were carried out at various ISRO Centres (VSSC, LPSC and ISAC). The periodic 
guidance of Dr Vedachalam, Dr Lalji Singh of CCMB, Dr T. K. Alex, LEOS, Mr V. Sundararamaiah and Mr Gnana Gandhi is acknowledged. We are grateful to Dr G. Madhavan Nair, Chairman, ISRO/ Secretary, DOS, for his encouragement and full support throughout the payload development and analysis. Our special thanks go to the India Air Force for the helicopter recovery of the payload. We thank Dr Jean P. Euzéby, Ecole Nationale Vétérinaire, Toulouse, France, for help with the nomenclature of the novel species. Y.S.S. would also like to thank the Department of Biotechnology, Government of India, for financial support.

\section{References}

Bruch, C. W. (1967). Microbes in the upper atmosphere and beyond. In Airborne Microbes (Society for General Microbiology Symposium no. 17), pp. 345-373. Edited by P. H. Gregory \& J. L. Monteith. Cambridge: Cambridge University Press.

Collins, M. D., Pirouz, T., Goodfellow, M. \& Minnikin, D. E. (1977). Distribution of menaquinones in actinomycetes and corynebacteria. J Gen Microbiol 100, 221-230.

Felsenstein, J. (1993). PHYLIP (phylogeny inference package), version 3.5c. Distributed by the author. Department of Genome Sciences, University of Washington, Seattle, USA.

Fromm, M., Bevilacqua, R., Stocks, B. \& Servanckx, R. (2004). New directions: eruptive transport to the stratosphere: add fire-convection to volcanoes. Atmos Environ 38, 163-165.

Gladman, B. J., Burns, J. A., Duncan, M., Lee, P. \& Levinson, H. F. (1996). The exchange of impact ejecta between terrestrial planets. Science 271, 1387-1392.

Greene, V. W., Pederson, P. D., Lundgren, D. A. \& Hagberg, C. A. (1964). Microbiological exploration of stratosphere: results of six experimental flights. In Proceedings of the Atmospheric Biology Conference, University of Minnesota, 13-15 April 1964, pp. 199-211. Washington, DC: National Aeronautics and Space Administration.

Harris, M. J., Wickramasinghe, N. C., Lloyd, D., Narlikar, J. V., Rajaratnam, P., Turner, M. P., Al-Mufti, S., Wallis, M. K., Ramadurai, S. \& Hoyle, F. (2002). Detection of living cells in stratospheric samples. In Instruments, Methods, and Missions for Astrobiology IV (Proceedings of the SPIE Conference 2001, vol. 4495), pp. 192-198. Edited by R. B. Hoover, G. V. Levin, R. R. Paepe \& A. Y. Rozanov. Bellingham, WA: SPIE.

Holding, A. J. \& Collee, J. G. (1971). Routine biochemical tests. Methods Microbiol 6A, 2-32.

Hoyle, F. \& Wickramasinghe, N. C. (1986). The case for life as a cosmic phenomenon. Nature 322, 509-511.

Hoyle, F. \& Wickramasinghe, N. C. (1993). Our Place in the Cosmos. London: J. M. Dent.

Hoyle, F. \& Wickramasinghe, N. C. (1999). Astronomical Origins of Life: Steps Towards Panspermia. Dordrecht: Kluwer.

Imshenetsky, A. A., Lysenko, S. V. \& Kazakov, G. A. (1978). Upper boundary of the biosphere. Appl Environ Microbiol 35, 1-5.

Kageyama, A., Takahashi, Y., Yasumoto-Hirose, M., Kasai, H., Shizuri, Y. \& Omura, S. (2007). Janibacter corallicola sp. nov., isolated from coral in Palau. J Gen Appl Microbiol 53, 185-189.

Kämpfer, P., Terenius, O., Lindh, J. M. \& Faye, I. (2006). Janibacter anophelis sp. nov., isolated from the midgut of Anopheles arabiensis. Int J Syst Evol Microbiol 56, 389-392.

Kimura, M. (1980). A simple method for estimating evolutionary rates of base substitutions through comparative studies of nucleotide sequences. J Mol Evol 16, 111-120.
Kiran, M. D., Prakash, J. S. S., Annapoorni, S., Dube, S., Kusano, T., Okuyama, H., Murata, N. \& Shivaji, S. (2004). Psychrophilic Pseudomonas syringae requires trans-monounsaturated fatty acid for growth at higher temperature. Extremophiles 8, 401-410.

Komagata, K. \& Suzuki, K. (1987). Lipid and cell-wall analysis in bacterial systematics. Methods Microbiol 19, 161-207.

Kumar, S., Tamura, K. \& Nei, M. (2004). MEGA3: integrated software for molecular evolutionary genetics analysis and sequence alignment. Brief Bioinform 5, 150-163.

Lang, E., Kroppenstedt, R. M., Swiderski, J., Schumann, P., Ludwig, W., Schmid, A. \& Weiss, N. (2003). Emended description of Janibacter terrae including ten dibenzofuran-degrading strains and Janibacter brevis as its later heterotypic synonym. Int J Syst Evol Microbiol 53, 1999-2005.

Lysenko, S. V. (1979). Microorganisms of the upper layers of the atmosphere. Mikrobiologiia 48, 1066-1074 (in Russian).

Mileikowsky, C., Cucinotta, F. A., Wilson, J. W., Gladman, B., Horneck, G., Lindegren, L., Melosh, J., Rickman, H., Valtonen, M. \& Zheng, J. Q. (2000). Natural transfer of viable microbes in space. Icarus 145, 391-427.

Nicholson, W. L., Munakata, N., Horneck, G., Melosh, H. J. \& Setlow, P. (2000). Resistance of Bacillus endospores to extreme terrestrial and extraterrestrial environments. Microbiol Mol Biol Rev 64, 548-572.

Pasko, V. P., Stanley, M. A., Mathews, J. D., Inan, U. S. \& Wood, T. G. (2002). Electrical discharge from thundercloud tops to the lower ionosphere. Nature 416, 152-154.

Pidiyar, V. J., Jangid, K., Patole, M. S. \& Shouche, Y. S. (2004). Studies on cultured and uncultured microbiota of wild Culex quinquefasciatus mosquito midgut based on $16 \mathrm{~S}$ ribosomal RNA gene analysis. Am J Trop Med Hyg 70, 597-603.

Reddy, G. S. N., Prakash, J. S. S., Prabahar, V., Matsumoto, G. I., Stackebrandt, E. \& Shivaji, S. (2003). Kocuria polaris sp. nov., an orange-pigmented psychrophilic bacterium isolated from an Antarctic cyanobacterial mat sample. Int J Syst Evol Microbiol 53, 183-187.

Rogers, L. A. \& Meier, F. C. (1936). In US Army Air Corps Stratosphere Flight of 1935 in the Balloon "Explorer II", pp. 146-151. Edited by L. J. Briggs. Washington, DC: National Geographic Society.

Rohatschek, H. (1996). Levitation of stratospheric and mesophilic aerosols by gravito-photophoresis. J Aerosol Sci 27, 467-475.

Saitou, N. \& Nei, M. (1987). The neighbor-joining method: a new method for reconstructing phylogenetic trees. Mol Biol Evol 4, 406-425.

Sato, N. S. \& Murata, N. (1988). Membrane lipids. Methods Enzymol 167, 251-259.

Shivaji, S., Ray, M. K., Rao, N. S., Saisree, L., Jagannadham, M. V., Kumar, G. S., Reddy, G. S. N. \& Bhargava, P. M. (1992). Sphingobacterium antarcticus sp. nov., a psychrotrophic bacterium from the soils of Schirmacher Oasis, Antarctica. Int J Syst Bacteriol 42, 102-116.

Shivaji, S., Bhanu, N. V. \& Aggarwal, R. K. (2000). Identification of Yersinia pestis as the causative organism of plague in India as determined by $16 \mathrm{~S}$ rDNA sequencing and RAPD-based genomic fingerprinting. FEMS Microbiol Lett 189, 247-252.

Shivaji, S., Chaturvedi, P., Reddy, G. S. N. \& Suresh, K. (2005). Pedobacter himalayensis sp. nov., from the Hamta glacier located in the Himalayan mountain ranges of India. Int J Syst Evol Microbiol 55, 1083-1088.

Shivaji, S., Chaturvedi, P., Suresh, K., Reddy, G. S. N., Rajaratnam, P., Wainwright, M., Narlikar, J. V. \& Bhargava, P. M. (2006). Bacillus aerius sp. nov., Bacillus aerophilus sp. nov., Bacillus stratosphericus sp. nov. and Bacillus altitudinis sp. nov., isolated from cryogenic tubes used for 
collecting air samples from high altitudes. Int J Syst Evol Microbiol 56, 1465-1473.

Smibert, R. M. \& Krieg, N. R. (1994). Phenotypic characterization. In Methods for General and Molecular Bacteriology, pp. 607-654. Edited by P. Gerhardt, R. G. E. Murray, W. A. Wood \& N. R. Krieg. Washington, DC: American Society for Microbiology.

Thompson, J. D., Higgins, D. G. \& Gibson, T. J. (1994). CLUSTAL W: improving the sensitivity of progressive multiple sequence alignment through sequence weighting, position-specific gap penalties and weight matrix choice. Nucleic Acids Res 22, 4673-4680.
Tourova, T. P. \& Antonov, A. S. (1987). Identification of microorganisms by rapid DNA-DNA hybridization. Methods Microbiol 19, 333355.

Wainwright, M., Wickramasinghe, N. C., Narlikar, J. V. \& Rajaratnam, P. (2003). Microorganisms cultured from stratospheric air samples obtained at $41 \mathrm{~km}$. FEMS Microbiol Lett 218 , 161-165.

Yoon, J. H., Lee, H. B., Yeo, S. H. \& Choi, J. E. (2004). Janibacter melonis sp. nov., isolated from abnormally spoiled oriental melon in Korea. Int J Syst Evol Microbiol 54, 1975-1980. 